\title{
ANALISIS PENGUKURAN KINERJA RUMAH SAKIT DENGAN PENDEKATANBALANCED SCORECARD PADA RUMAH SAKIT DAERAH MADANI PALU TAHUN 2015
}

\author{
Olivia H. Munayang ${ }^{1}$, Ririn Parmita ${ }^{2}$, Andini Nurhajra ${ }^{3}$ \\ ${ }^{123}$ Sekolah Tinggi Ilmu Ekonomi (STIE) Panca Bhakti Palu \\ 1sultanandini@gmail.com
}

\begin{abstract}
Abstrak
Penelitian ini menggunakan pendekatan Balanced Scorecard, di mana hal ini dilakukan penelitian karena masih ada kinerja yang harus diketahui tidak hanya keuangan saja tetapi dari segi non keuangan juga. Penelitian ini bertujuan untuk menganalisis kinerja Rumah Sakir Daerah Madani dengan empat perspektif yaitu perspektif pelanggan, perspektif proses bisnis internal, perspektif pembelajaran dan pertumbuhan serta perspektif keuangan. Untuk perspektif pelanggan menggunakan 98 responden, perspektif proses bisnis internal dan perspektif pembelajaran dan pertumbuhan menggunakan 84 responden dan untuk perspektif keuangan menggunakan laporan keuangan Rumah Sakit periode 2015. Hasil pengukuran kinerja Rumah Sakit dengan menggunakan pendekatan Balanced Scorecard memperoleh hasil atau skor 0,7. Hasil ini menunjukkan bahwa kinerja Rumah Sakit dilihat dari pengukuran kinerja secara keseluruhan dikatakan Baik. Meskipun kinerja masingmasing perspektif belum maksimal, namun hal ini dapat menunjukkan kinerja yang baik bagi Rumah Sakit Daerah Madani. Penggunaan pengukuran balanced scorecard dalam organisasi dapat memberikan gambaran umum mengenai kinerja suatu organisasi yang lebih lengkap dan komprehensif.
\end{abstract}

Kata Kunci : Balanced Scorecard, Rumah Sakit, dan Kinerja.

\section{ANALYSIS OF HOSPITAL PERFORMANCE MEASUREMENT WITH BALANCED SCORECARD APPROACH IN THE REGIONAL HOSPITAL OF MADANI, PALU 2015}

\author{
Olivia H. Munayang ${ }^{1}$, Ririn Parmita ${ }^{2}$, Andini Nurhajra ${ }^{3}$ \\ ${ }^{123}$ Sekolah Tinggi Ilmu Ekonomi (STIE) Panca Bhakti Palu \\ ${ }^{1}$ sultanandini@gmail.com
}

\begin{abstract}
This study uses the Balanced Scorecard approach, where this is done research because there is still a performance that must be known not only finance but in terms of non-financial as well. This study aims to analyze the performance of Regional Hospital of Madani with four perspectives; customer perspective, internal business process perspective, learning and growth perspective and financial perspective. For customer perspective, it involves 98 respondents, internal business process perspective and learning and growth perspective involves 84 respondents and for financial perspective uses hospital financial statements of 2015 period. Hospital performance measurement result using Balanced Scorecard approach obtained result or score 0,7. These results indicate that hospital performance seen from overall performance measurement is Good. Although the performance of each perspective has not been maximal, but this can show good performance for the Regional Hospital of Madani. The use of balanced scorecard measurements within an organization can provide an overview of the performance of a more complete and comprehensive organization.
\end{abstract}


Keywords: Balanced Scorecard, Hospital, and Performance.

\section{PENDAHULUAN}

Menilai keberhasilan perusahaan dan pemberian imbalan atau insentif bagi karyawan, dibutuhkan suatu indicator dalam bentuk pengukuran kinerja perusahaan. Namun selama ini, sebagian besar pengukuran kinerja yang diterapkan oleh perusahaan hanya menitikberatkan pada sisi keuangan saja. Perusahaan dianggap berhasil apabila menghasilkan pencapaian keuangan yang tinggi.

Padahal, dalam mengukur kinerja suatu perusahaan tidak hanya melihat dari sisi keuangan, tetapi juga non keuangan.

Berdasarkan analogi tersebut diatas, dapat disimpulkan bahwa pengukuran keuangan saja tidak akan dapat memberikan gambaran yang rill mengenai keadaan perusahaan. Untuk dapat mengukur kinerja perusahaan secara keseluruhan, maka diciptakan suatu metode pendekatan yang mempertimbangkan empat aspek, antara lain keuangan atau finansial, pelanggan, proses bisnis internal serta proses belajar dan berkembang.

Rumah sakit sebagai salah satu jenis Badan Layanan Umum (BLU) yang menyelenggarakan pelayanan kesehatan masyarakat dan menurut Undang- Undang Dasar 1945 pasal 28H ayat (1) setiap orang berhak memperoleh pelayanan kesehatan. Oleh karena itu, ketersediaan pelayanan kesehatan yang merata, bermutu dan berorientasi kepada kepuasan pasien merupakan tuntutan yang harus dipenuhi oleh rumah sakit. Hal ini berarti bahwa rumah sakit dituntut untuk memiliki kinerja yang baik. Untuk memenuhi tuntutan tersebut tentu saja rumah sakit harus didukung oleh dana, sumber daya manusia yang bermutu dan professional serta peralatan yang memadai.

Rumah Sakit Daerah Madani sebagai Badan Layanan Umum Daerah (BLUD) dituntut untuk terus menerus meningkatkan kinerjanya agar dapat mempertahankan statusnya sebagai Badan Layanan Umum Daerah (BLUD) secara maksimal. Berdasarkan data LAKIP Tahun 2015 diketahui kinerja Rumah Sakit Daerah Madani telah menggunakan Balanced Scorecard dimana data ini dilihat dari perspektif keuangan, perspektif pelanggan, perspektif proses bisnis internal dan perspektif pembelajaran dan pertumbuhan. Selengkapnya dapat dilihat pada tabel 1 .

Berdasarkan tabel 1., dapat diketahui nilai atau capaian RSD Madani dari perspektif kinerja keuangan sebesar 19,15 masih berada dibawah bobot kinerja yang dipersyaratkan yaitu sebesar 30 . 
JRAMB, Prodi Akuntansi, Fakultas Ekonomi, UMB Yogyakarta

Volume 3 No. 1., Mei 2017

Tabel 1. Hasil Penilaian Kinerja Kuangan RSD Madani Tahun 2015

\begin{tabular}{|c|c|c|c|c|}
\hline No & Uraian & Skor & $\begin{array}{c}\text { Nilai } \\
\text { (Capaian RSD) }\end{array}$ & $\%$ \\
\hline & \multicolumn{4}{|l|}{ Aspek Keuangan } \\
\hline \multirow[t]{11}{*}{1.} & Rasio Keuangan & & & \\
\hline & a. Rasio Kas (Cash Ratio) & 2,00 & 1,50 & 75,00 \\
\hline & b. Rasio Lancar (Current Ratio) & 2,50 & 2,50 & 100,00 \\
\hline & c. Periode Penagihan Piutang (Collection Period) & 2,00 & 1,00 & 50,00 \\
\hline & $\begin{array}{l}\text { d. Perputaran Aset Tetap (Fixed Asset Turnover) } \\
\text { e. Imbalan atas Aset Tetap (Return on Fixed }\end{array}$ & 2,00 & 2,00 & 100,00 \\
\hline & Asset) & 2,00 & - & 0,00 \\
\hline & f. Imbalan Ekuitas (Return on Equity) & 2,00 & - & 0,00 \\
\hline & $\begin{array}{l}\text { g. Perputaran Persediaan (Inventory Turnover) } \\
\text { h. Rasio Pendapatan PNBP terhadap Biaya }\end{array}$ & 2,00 & 2,00 & 100,00 \\
\hline & Operasional & 2,50 & 1,75 & 70,00 \\
\hline & i. Rasio Subsidi Biaya Pasien & 2,00 & - & 0,00 \\
\hline & Total & 19,00 & 10,75 & 56,58 \\
\hline \multirow[t]{14}{*}{2.} & Kepatuhan Pengelolaan Keuangan RSD & & & \\
\hline & $\begin{array}{l}\text { a. Rencana Bisnis dan Anggaran (RBA) Definitif } \\
\text { b. Laporan Keuangan Berdasarkan Standar }\end{array}$ & 2,00 & 0,40 & 20,00 \\
\hline & $\begin{array}{l}\text { Akuntansi Keuangan } \\
\text { c. Surat Perintah Pengesahan Pendapatan dan }\end{array}$ & 2,00 & 1,00 & 50,00 \\
\hline & Belanja BLC & 2,00 & 2,00 & 100,00 \\
\hline & d. Tarif Layanan & 1,00 & 1,00 & 100,00 \\
\hline & e. Sistem Akuntansi & 1,00 & 1,00 & 100,00 \\
\hline & f. Persetujuan Rekening & 0,50 & 0,50 & 100,00 \\
\hline & g. SOP Pengelolaan Kas & 0,50 & 0,50 & 100,00 \\
\hline & h. SOP Pengelolaan Piutang & 0,50 & 0,50 & 100,00 \\
\hline & i. SOP Pengelolaan Utang & 0,50 & 0,50 & 100,00 \\
\hline & j. SOP Pengadaan Barang dan Jasa & 0,50 & 0,50 & 100,00 \\
\hline & k. SOP Pengelolaan Barang Inventaris & 0,50 & 0,50 & 100,00 \\
\hline & Total & $\mathbf{1 1 , 0 0}$ & 8,40 & 76,36 \\
\hline & Jumlah Aspek Keuangan & $\mathbf{3 0 , 0 0}$ & 19,15 & 63,83 \\
\hline
\end{tabular}

Sumber LAKIP RSD. Madani Tahun 2015

Hal ini disebabkan belum optimalnya aspek keuangan baik dilihat dari sub aspek rasio keuangan maupun sub aspek kepatuhan pengelolaan keuangan Rumah Sakit Daerah.

Jika dilihat dari sub aspek rasio keuangan, belum optimalnya pencapaian tersebut diantaranya disebabkan oleh Rumah Sakit Daerah Madani terlalu besarnya nominal kas/setara kas yang tersimpan, lamanya periode penagihan atas piutang Rumah Sakit Daerah, pendapatan yang masih bersumber dari APBD, besarnya biaya operasional, dan Rumah Sakit Daerah Madani tidak pernah 
memberikan subsidi/keringanan kepada pasien tidak mampu.

Selain menggunakan Perspektif Keuangan, capaian Rumah Sakit Daerah
Madani dilihat dari perspektif pelanggan atau dari indikator mutu pelayanan kesehatan dapat dilihat pada Tabel 2. sebagai berikut:

Tabel 2. Indikator Kinerja Perspektif Pelanggan Tahun 2015

\begin{tabular}{clccc}
\hline No & \multicolumn{1}{c}{ Uraian } & Skor & $\begin{array}{c}\text { Nilai } \\
\text { (Capaian RSD) }\end{array}$ & \% \\
\hline 1. & Mutu Pelayanan & 14,00 & 10,50 & 60,71 \\
2. & Mutu Klinik & 12,00 & 12,00 & 66,67 \\
3. & Kepedulian Kepada Masyarakat & 4,00 & 2,00 & 50,00 \\
4. & Kepuasan Pelanggan & 2,00 & 0,00 & 0,00 \\
5. & Kepedulian Terhadap Lingkungan & 3,00 & 0,40 & 13,33 \\
\hline \multicolumn{2}{c}{ Total } & $\mathbf{3 5 , 0 0}$ & $\mathbf{2 4 , 9 0}$ & $\mathbf{5 4 , 0 0}$ \\
\hline
\end{tabular}

Sumber : LAKIP RSD. Madani Tahun 2015

Capaian kinerja perspektif

pelanggan yaitu sebesar 24,90 masih

berada dibawah bobot kinerja yang dipersyaratkan sebesar 35. Hal ini disebabkan karena dari lima sub indikator yang ada, empat sub indikator kinerja perspektif pelanggan masih belum optimal. Ke empat sub indikator tersebut yaitu mutu pelayanan, kepedulian kepada masyarakat, kepuasan pelanggan dan kepedulian terhadap lingkungan.

Kurang maksimalnya capaian sub indikator mutu pelayanan dikarenakan ketidaksesuaian antara standar yang telah ditetapkan dengan kenyataan yang terjadi di lapangan. Misalnya lamanya length of stay, lamanya penyediaan obat, tidak tersedia data rekapitulasi waktu pelaksanaan operasi, serta lamanya waktu tunggu hasil radiologi.

Untuk sub indikator kepedulian kepada masyarakat penyebab tidak optimalnya subindikator ini disebabkan oleh Rumah Sakit Daerah tidak mempunyai program pembinaan/ penyuluhan tentang kesehatan kepada Puskesmas/ Kelompok Masyarakat. Kurang maksimalnya capaian indikator kepuasan pelanggan disebabkan oleh Rumah Sakit Daerah belum menindaklanjuti secara tertulis atas komplain dan belum melakukan penilaian atas kepuasan pelanggan/pasien.

Sedangkan penyebab tidak optimalnya sub indikator kepedulian terhadap lingkungan disebabkan oleh Rumah Sakit Daerah belum mempunyai program kebersihan lingkungan/program Rumah Sakit Berseri/Green Hospital.

Untuk perspektif proses bisnis internal dan perspektif pembelajaran dan pertumbuhan Rumah Sakit Daerah Madani maka indikator yang digunakan yaitu pertumbuhan produktifitas, 
efektivitas pelayanan, dan pertumbuhan

dilihat pada Tabel 3. seperti berikut ini: pembelajaran. Hasil kinerja tersebut dapat

Tabel 3. Perspektif Proses Bisnis Internal dan Perspektif Pembelajaran dan Pertumbuhan Tahun 2015

\begin{tabular}{llccc}
\hline No & \multicolumn{1}{c}{ Uraian } & Bobot & $\begin{array}{c}\text { Nilai } \\
\text { (Capaian RSD) }\end{array}$ & $\mathbf{\%}$ \\
\hline 1. & Pertumbuhan Produktifitas & 18,00 & 17,00 & 94,44 \\
2. & Efektivitas Pelayanan & 14,00 & 8,00 & 35,71 \\
3. & Pertumbuhan Pembelajaran & 3,00 & 0,50 & 16,67 \\
\hline \multicolumn{2}{r}{ Total } & $\mathbf{3 5 , 0 0}$ & $\mathbf{2 5 , 5 0}$ & $\mathbf{6 4 , 2 9}$ \\
\hline
\end{tabular}

Sumber : LAKIP RSD. Madani tahun 2015

Dari hasil kinerja perspektif proses bisnis internal dan perspektif pembelajaran dan pertumbuhan diatas maka, nilai kinerja sebesar 25,50 masih berada dibawah bobot kinerja yang dipersyaratkan yaitu sebesar 35. Hal ini disebabkan karena efektifitas pelayanan dan pertumbuhan pembelajaran masih belum memberikan hasil yang optimal seperti rekam medik pasien yang belum lengkap, tidak tersedia beberapa data rekapitulasi (data jumlah semua rekam medik tahun 2015, data pembatalan operasi yang sudah dijadwalkan selama satu tahun, jenis obat yang diresepkan), minimnya tempat tidur pasien, serta belum adanya program reward and punishment dan jam pelatihan pegawai di bawah 20 jam.

Penilaian kinerja Rumah Sakit Daerah Madani tahun 2015 yang dilakukan meliputi perspektif keuangan, pelanggan, proses bisnis internal dan pembelajaran dan pertumbuhan. Maka dapat disimpulkan bahwa hasil dari perhitungan dapat dilihat pada Tabel 4 . sebagai berikut:

Tabel 4. Hasil Penilaian Kinerja Rumah Sakit Daerah Madani

\begin{tabular}{llcc}
\hline No & \multicolumn{1}{c}{ Uraian } & $\begin{array}{c}\text { Nilai } \\
\text { Kesehatan }\end{array}$ & $\begin{array}{c}\text { Bobot } \\
\text { Penilaian }\end{array}$ \\
\hline 1. & Perspekti Keuangan & 19,15 & 30 \\
2. & $\begin{array}{l}\text { Perspektif Pelanggan } \\
\text { 3. }\end{array}$ & 24,90 & 35 \\
& $\begin{array}{l}\text { Perspektif proses bisnis internal dan perspektif } \\
\text { pembelajaran dan pertumbuhan }\end{array}$ & 25,50 & 35 \\
\hline & & \\
\hline & Jumlah & $\mathbf{6 9 , 5 5}$ & $\mathbf{1 0 0}$ \\
\hline
\end{tabular}

Hasil penilaian masing-masing dari nilai maksimum 100 atau dengan perspektif pada Rumah Sakit Daerah tingkat kesehatan "sehat".

Madani tahun 2015 adalah sebesar 69,55

Dari hasil kinerja Rumah Sakit Daerah Madani dengan menggunakan 
balanced scorecard di atas, belum terlihat bahwa masing-masing perspektif dapat mendalami masalah yang ada dengan memberikan kuisioner kepada pelanggan atau pegawai agar dapat mengetahui kepuasan pelanggan terhadap Rumah Sakit Daerah Madani Palu.

Hasil kinerja ini melihat seberapa besar kunjungan pasien kerumah sakit, kecepatan pelayanan dan juga penggunaan tempat tidur dan lain-lain, tanpa melihat hal-hal yang masih kurang dan belum memberikan pertanyaanpertanyaan secara terbuka. Sedangkan pada penelitian yang akan dilakukan peneliti yaitu dengan menggunakan variabel-variabel yang penting dalam pengukuran kinerja balanced scorecard dengan memberikan kuesioner kepada pelanggan dan karyawan, untuk memberikan informasi yang lebih akurat sebagai hal-hal yang penting untuk dijadikan suatu acuan terhadap Rumah Sakit Daerah Madani. Dengan informasi tersebut maka pihak manajemen Rumah Sakit Daerah Madani dapat mengetahui permasalahan-permasalahan yang menyimpang dari tujuan yang telah ditetapkan sehingga pimpinan dapat memperbaiki kinerjanya diperiodeperiode berikutnya.

Melihat fenomena tersebut diatas, maka penulis memilih menggunakan alternatif pengukuran kinerja dengan pendekatan Balanced Scorecard pada Rumah Sakit Daerah Madani di Provinsi Sulawesi Tengah Tahun 2015 yang lebih kompherensif, dan akurat, dan memeberikan informasi kepada pihak rumah sakit secara lebih jelas.

$$
\text { Dewi Suryani at.al }
$$

melakukan penelitian dengan judul "Perancangan Balanced Scorecard Untuk Pengembangaan Strategi Di SEAMEO BIOTROP". Hasil penelitian menunjukkan bahwa dalam perspektif keuangan jumlah dana yang diterima dari Pemerintah menunjukkan kontribusi tertinggi terhadap kinerja lembaga, sedangkan pada perspektif pelanggan, jumlah penelitian/program regular/baru yang dilakukan bekerja sama dengan organisasi akademisi, penelitian dan pengembangan dan industri terkait lainnya menunjukkan kontribusi tertinggi terhadap kinerja lembaga. Pada perspektif proses bisnis internal, MOU yang ditandatangani dan diimplementasikan menunjukkan kontribusi tertinggi terhadap kinerja lembaga tersebut, dan perspektif pertumbuhan dan pembelajaran, rasio produktivitas tenaga kerja menunjukkan kontribusi tertinggi terhadap kinerja lembaga.

Luh Putu Lusi Setyandaria Surya (2014) dengan judul "Analisis Kinerja Berbasis Balanced Scorecard Pada Koperasi XYZ". Metode penelitian yang 
digunakan adalah indeks kepuasan karyawan (IKK) produktivitas karyawan, tingkat perkembangan jenis usaha, tingkat pertumbuhan anggota sebagai indeks Kepuasan Pelanggan (IKP), Return On Equity (ROE) dan rata - rata sisa hasil usaha. Berdasarkan hasil analisis, diketahui bahwa kinerja dari keempat perspektif balanced scorecard pada koperasi XYZ adalah beragam. Terdapat penurunan dari perspektif keuangan, sedangkan untuk ketiga perspektif lainnya menghasilkan kinerja yang baik.

\section{Pengukuran Kinerja Sektor Publik}

Menurut Slamet

$(2007: 125)$

pengukuran kinerja adalah proses evaluasi seberapa baik seorang pekerja memperkerjakan mereka ketika dibandingkan dengan satu set standar dan kriteria kemudian mengkomunikasikannya. Definisi lain disampaikan oleh Mulyadi dan Setyawan (2001:353) bahwa penilaian kinerja adalah penentuan secara periodik mengenai efektivitas operasional suatu organisasi, bagian organisasi dan kegunaannya berdasarkan sasaran, standar dan kriteria yang telah ditetapkan sebelumnya.

Menurut Mardiasmo (2002:121) pengukuran kinerja adalah suatu sistem yang bertujuan untuk membantu manajer publik menilai pencapaian suatu strategi melalui alat ukur finansial dan non finansial. Sistem pengukuran kinerja dapat dijadikan sebagai alat pengendalian organisasi, karena pengukuran kinerja dapat diperkuat dengan menetapkan reward dan purishment system.

Selanjutnya menurut Simons dalam BPKP, (2004) menyatakan bahwa pengukuran kinerja membantu manajer dalam memonitor implementasi strategi dengan cara membandingkan hasil nyata dengan sasaran data tujuan strategis.

Dari berbagai definisi dapat disimpulkan bahwa pengukuran kinerja adalah proses evaluasi secara periodik efektivitas berbagai aktifitas dalam rantai nilai yang ada diperusahaan dengan cara membandingkan kegiatan yang ada dengan satu set standard dan kriteria yang telah ditetapkan sebelumnya, kemudian mengkomunikasikannya dengan tujuan untuk membantu kinerja publik menilai pencapaian finansial dan non finansial.

\section{Definisi Balanced Scorecard}

Menurut Dhika Pratiwi dalam (Mulyadi 2005:2) Balanced Scorecard merupakan pendekatan yang menunjukkan visi dan strategi perusahaan ke dalam tujuan-tujuan dan pengukuranpengukuran yang dilihat dari empat perspektif satu menerjemahkan visi unit bisnis dan strateginya kedalam tujuan dan pengukuran yang berwujud dimana 
pengukuran tersebut mencerminkan keseimbangan antara hal-hal sebagai berikut:

a. Pengukuran hasil ( pada masa lalu)

b. Pengukuran eksternal dengan pengukuran internal

c. Pengukuran kinerja keuangan dan non keuangan.

d. Proses Up-Down yang merupakan suatu penyebaran dan visi, misi dan strategi dengan proses Bottom-Up dimana hasil pengukuran ditingkat operasional didorong untuk memberikan umpan balik guna mengevaluasi strategi tersebut.

e. Pengukuran-pengukuran atas hasil yang dilihat secara objektif, data kuantitaf dan unsure subjektif yang menjadi pertimbangan-pertimbangan manajerial.

f. Tujuan jangka pendek dan jangka panjang.

Kaplan dan Norton (1996:129) menerapkan Balanced Scorecard, dan mensyaratkan dipegangnya Lima prinsip utama sebagai berikut:

1. Menerjemahkan sistem manajemen strategi berbasis Balanced Scorecard ke dalam terminologi operasional sehingga semua orang dapat memahami
2. Menghubungkan dan menyelaraskan organisasi dengan strategi itu. Ini untuk memberikan arah dari eksekutif kepada staf garis depan

3. Membuat strategi merupakan pekerjaan bagi semua orang melalui kontribusi setiap orang dalam implementasi strategis

4. Membuat strategi suatu proses terus menerus melalui pembelajaran dan adaptasi organisasi

5. Melaksanakan agenda perubahan oleh eksekutif guna memobilisasi perubahan.

Konsep Balanced Scorecard berkembang sejalan dengan perkembangan pengimplementasian konsep tersebut. Pada tahap awal eksperimennya, Balanced Scorecard merupakan kartu skor yang digunakan untuk mencatat hasil skor kinerja eksekutif. Melalui kartu skor, skor yang hendak diwujudkan eksekutif dimasa mendatang dibandingkan dengan hasil kinerja sesungguhnya. Hasil perbandingan ini digunakan untuk evaluasi atas kinerja eksekutif.

\section{Pengembangan Organisasi Sektor}

\section{Publik dengan Balanced Scorecard}

Pengembangan

organisasi

merupakan upaya meningkatkan 
kemampuan organisasi berdasarkan

keberhasilan

mereka

melalui

persepektif waktu jangka panjang yang kemampuan mengatur pengeluaran terdiri dari serangkaian penahapan dengan penekanan pada hubungan antar individu, kelompok dan organisasi sebagai keseluruhan. Pengembangan organisasi dapat juga dikatakan aplikasi pendekatan kesisteman terhadap hubungan fungsional, struktural, teknikal, dan personal dalam organisasi.

Pengembangan organisasi sejumlah anggaran yang berwujud pada kebutuhan masyarakat, instansi pemerintah lain dan pemerintah pusat (stakeholders). Dengan demikian, fokus utama organisasi pemerintah bukan pada pencapaian tujuan finansial namun pada tujuan yang berfokus pada pelanggan, yang dalam hal ini adalah masyarakat dan pemerintah pusat.

merupakan suatu perubahan organisasi, oleh karena itu Siagian (1995:21) mengatakan bahwa persepsi tentang perlunya perubahan harus dirasakan karena hanya dalam kondisi demikianlah para anggota organisasi dapat diyakinkan bahwa dalam upaya mencapai tujuan dan berbagai sasaran organisasi, diperlukan cara kerja baru, metode kerja baru, dan bahkan mungkin strategi dan visi yang baru. Salah satu ciri umum pengembangan organisasi adalah bahwa pengembangan organisasi merupakan suatu proses yang terus menerus dan dinamis. Pelaksana harus mampu mengubah strategi selama proses sedang berlangsung sebagai akibat masalahmasalah yang timbul dan kejadiankejadian organisasi.

\section{Menurut Gaspersz, (2006:210)}

Tujuan finansial bukan merupakan tujuan utama yang memadai untuk sektor publik. Organisasi sector publik mengukur

\section{Kerangka Pemikiran}

Keberhasilan perusahaan dapat dilihat dari kinerja perusahaan. Dalam hal ini pengukuran kinerja perusahaan hanya dilihat dari kinerja keuangannya saja tanpa melihat kinerja non keuangan. Dalam balanced scorecard dapat melihat kinerja secara keseluruhan baik keuangan maupun non keuangannya.

Balanced scorecard memperluas ukuran kinerja mulai dari perspektif keuangan, perspektif pelanggan, perspektif proses bisnis internal, dan perspektif pembelajaran dan pertumbuhan. Dari pengukuran tersebut kinerja perusahaan dapat diketahui keadaan Rumah Sakit Madani masuk dalam kategori baik maupun kurang baik.

Rumah sakit sebagai salah satu jenis BLU yang menyelenggarakan pelayanan kesehatan masyarakat dan menurut Undang- Undang Dasar 1945 
pasal $28 \mathrm{H}$ ayat (1) setiap orang berhak memperoleh pelayanan kesehatan. Oleh karena itu, ketersediaan pelayanan kesehatan yang merata, bermutu dan berorientasi kepada kepuasan pasien merupakan tuntutan yang harus dipenuhi oleh rumah sakit. Hal ini berarti bahwa rumah sakit dituntut untuk memiliki kinerja yang baik.

Dalam penelitian ini akan dilakukan pengukuran kinerja dengan menggunakan sistem pengukuran kinerja yang disebut Balanced Scorecard kepada sebuah Rumah Sakit. Dalam pendekatan Balanced Scorecard keempat perspektif tersebut menjadi satu kesatuan yang tidak dapat dipisahkan, juga merupakan indikator pengukuran kinerja yang saling melengkapi dan memiliki hubungan sebab akibat. Kaplan dan Norton (2001) menyorot empat perspektif utama melalui Balanced Scorecard yaitu

1. Perspektif konsumen atau pelanggan

2. Perspektif keuangan

3. Perspektif proses internal bisnis

4. Perspektif pembelajaran dan pertumbuhan

Untuk lebih jelasnya kerangka pemikiran dalam penelitian ini dapat digambarkan dengan gambar 1. sebagai berikut:

\section{Gambar 1. Kerangka Pemikiran Penelitian}

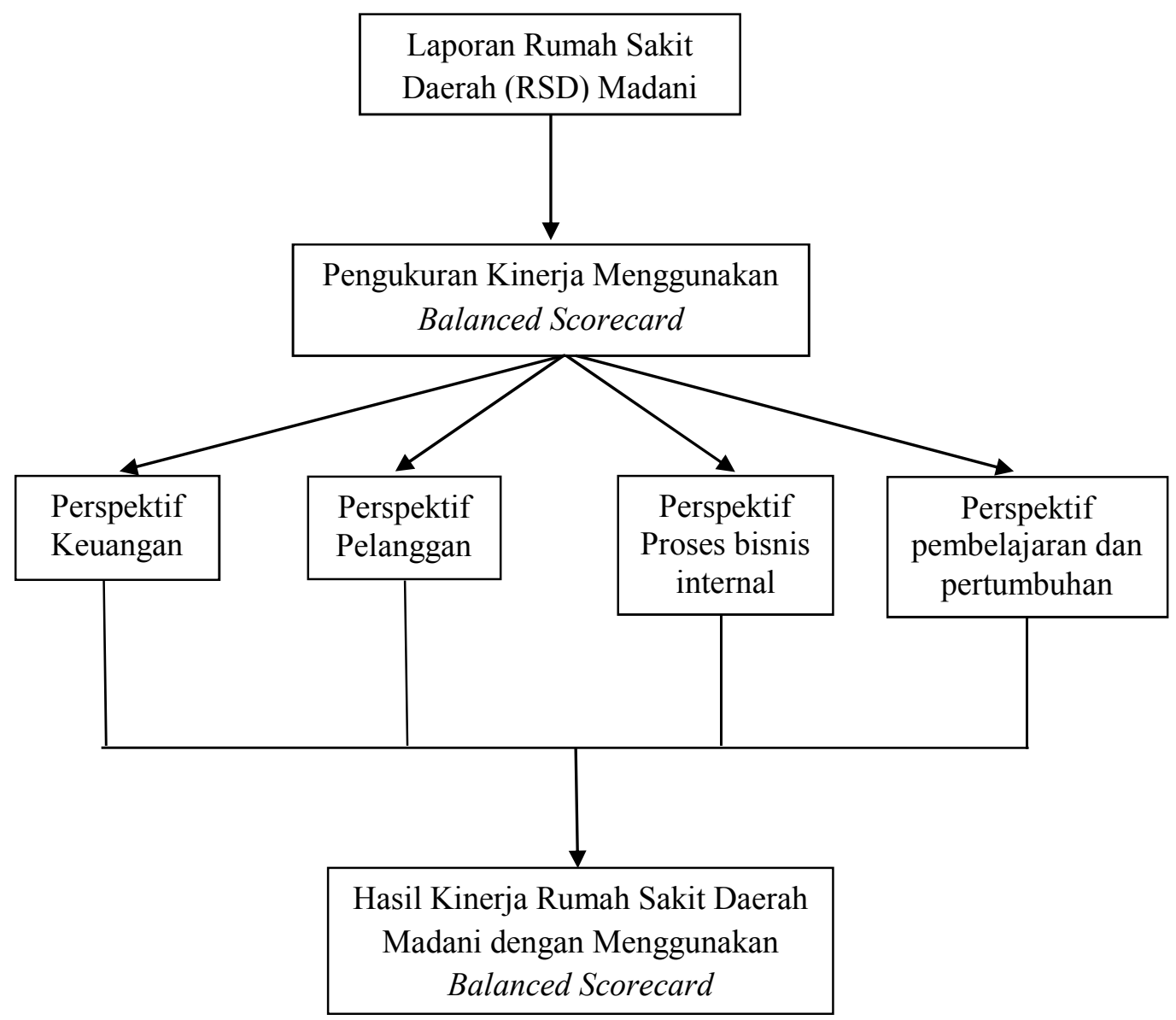




\section{METODE}

\section{Jenis Penelitian}

Penelitian ini menggunakan pendekatan deskriptif kualitatif dan kuantitatif yaitu pendekatan yang dilakukan dengan menganalisis data ordinal dari hasil jawaban kuesioner responden dan data-data angka (rasio) yang diperoleh dalam pengumpulan data.

Setelah data dianalisis, kemudian hasilnya dipaparkan secara deskriptif. Metode pengumpulan data yang digunakan adalah metode survey untuk memperoleh data primer secara langsung dari sumber asli. Metode ini merupakan metode pengumpulan data primer yang tertulis dan lisan yang memerlukan adanya kontak atau hubungan antara peneliti dengan subjek (responden) untuk memperoleh data yang diinginkan.

\section{Populasi dan Tekhnik Pengambilan Sampel \\ Populasi dalam penelitian ini terdiri} dari dua macam yaitu : 1) pasien untuk mengukur kinerja di perspektif pelanggan berjumlah 4. 602 pasien dan 2) pegawai untuk mengukur perspektif proses bisnis internal serta perspektif pembelajaran dan pertumbuhan adalah pegawai negeri sipil Rumah Sakit Daerah Madani berjumlah 540 orang. menggunakan pertanyaan atau pernyataan

Tabel 5. Daftar Pasien Berdasarkan Instalasi Pelayanan Pada Rumah Sakit Daerah Madani Tahun 2015

\begin{tabular}{clc}
\hline No & \multicolumn{1}{c}{ Kalsifikasi Ruangan/Kelas } & Jumlah \\
\hline 1 & Ruangan Melon terdiri dari : & 1201 Pasien \\
& 1. VIP & 186 Pasien \\
& 2. Kelas 1 & 415 Pasien \\
& 3. Kelas II & 600 Pasien \\
2 & Ruangan Nangka (Bedah) & 980 Pasien \\
3 & Ruangan Jambu (Penyakit Dalam) & 816 Pasien \\
4. & Ruangan Rambutan (Anak ) & 745 Pasien \\
5. & Ruangan Markisa (VIP Utama) & 310 Pasien \\
6. & Ruangan Semangka (Kamar Bersalin) & 550 Pasien \\
\hline \multicolumn{2}{c}{ Jumlah }
\end{tabular}

Sumber : Rekam Medis RSD Madani tahun 2015

Tabel 6. Daftar PNS Rumah Sakit Madani Tahun 2015

\begin{tabular}{|c|c|c|}
\hline No & Klasifikasi Profesi & Jumlah \\
\hline 1 & Tenaga Medis & 31 Orang \\
\hline 2 & Para Medis & 377 Orang \\
\hline 3 & Non Medis & 132 Orang \\
\hline & Jumlah & 540 Orang \\
\hline
\end{tabular}

Sumber : Sub. Bagian Tata Usaha RSD Madani Tahun 2015

Daftar PNS Rumah Sakit Daerah diantaraya yaitu terdiri dari tenaga medis Madani yaitu berjumlah 540 orang berjumlah 31 orang, para medis berjumlah 
377 orang, dan non medis

berjumlah 132 orang. Dari daftar tersebut maka jumlah keseluruhan populasi Pegawai Negeri Sipil Rumah Sakit Daerah Madani yaitu 540 orang.

\section{Teknik Pengambilan Sampel}

Metode pengambilan sampel dalam penelitian ini adalah metode Proporsional Random Sampling. Berdasarkan populasi pasien tahun 2015 sebanyak 4.602 pasien. Adapun besarnya sampel ditetapkan menurut rumus Slovin dengan tingkat kepercayaan 90\% maka jumlah sampel yang harus diambil sebesar 98 pasien dan untuk karyawan berjumlah 100 orang, yang ditetapkan dengan menggunakan rumus sebagai berikut :

$$
\begin{aligned}
& \mathrm{n}=\mathrm{N} /\left(1+\mathrm{Ne}^{2}\right) \\
& \mathrm{n}=\text { jumlah sampel }
\end{aligned}
$$

$$
\begin{gathered}
\mathrm{N}=\text { jumlah populasi } \\
\mathrm{e}=\text { toleransi tingkat kesalahan } \\
n=\frac{4.602}{1+4.602(0,10)^{2}}=\frac{4.602}{1+46,02} \\
=97,8=98
\end{gathered}
$$$$
n=\frac{540}{1+540(0,10)^{2}}=\frac{540}{1+5,40}
$$$$
=84,4=84
$$

Hasil perhitungan diatas maka, dapat diketahui jumlah sampel yang dapat ditarik sebagai responden dari masingmasing perspektif antara lain perspektif pelanggan, perspektif proses bisnis internal dan perspektif pembelajaran dan pertumbuhan dengan masing-masing sampel yaitu perspektif pelanggan berjumlah 98 sampel dan perspektif

\begin{tabular}{|c|c|c|}
\hline No & Klasifikasi Ruangan/Kelas & Jumlah Sampel \\
\hline \multirow{4}{*}{1.} & Ruangan Melon terdiri dari & \\
\hline & 1. VIP $=186 / 4.602 \times 98$ & 4 Pasien \\
\hline & 2. Kelas $1=415 / 4.602 \times 98$ & 9 Pasien \\
\hline & 3. Kelas II $=600 / 4.602 \times 98$ & 12 Pasien \\
\hline 2. & Ruangan Nangka $=980 / 4.602 \times 98$ & 20 Pasien \\
\hline 3. & Ruangan Jambu $=816 / 4.602 \times 98$ & 18 Pasien \\
\hline 4. & Ruangan Rambutan $=745 / 4.602 \times 98$ & 16Pasien \\
\hline 5. & Ruangan Markisa $=310 / 4.602 \times 98$ & 7 Pasien \\
\hline \multirow[t]{2}{*}{6.} & Ruangan Semangka $=550 / 4.602 \times 98$ & 12 Pasien \\
\hline & Jumlah Sampel & 98 Pasien \\
\hline \multicolumn{3}{|c|}{$\begin{array}{c}\text { Sumber : Sub. Bagian Tata Usaha RSD Madani Tahun } 2015 \\
\text { Tabel 8. Besar Sampel Per Proporsi }\end{array}$} \\
\hline No & Klasifikasi Profesi & Jumlah Sampel \\
\hline 1 & Medis $=31 / 540 \times 84$ & 5 Orang \\
\hline 2 & Para Medis $=377 / 540 \times 84$ & 59 Orang \\
\hline 3 & Non Medis $=132 / 540 \times 84$ & 20 Orang \\
\hline & Jumlah Sampel & 84 Orang \\
\hline
\end{tabular}
proses bisnis internal serta pembelajaran dan pertumbuhan berjumlah 84 sampel.Sampel dapat dilihat pada tabel 7 dan 8 berikut :

Tabel 7. Besar Sampel Per Proporsi 
JRAMB, Prodi Akuntansi, Fakultas Ekonomi, UMB Yogyakarta

Volume 3 No. 1., Mei 2017

Tabel 9. Variabel dan Indikator

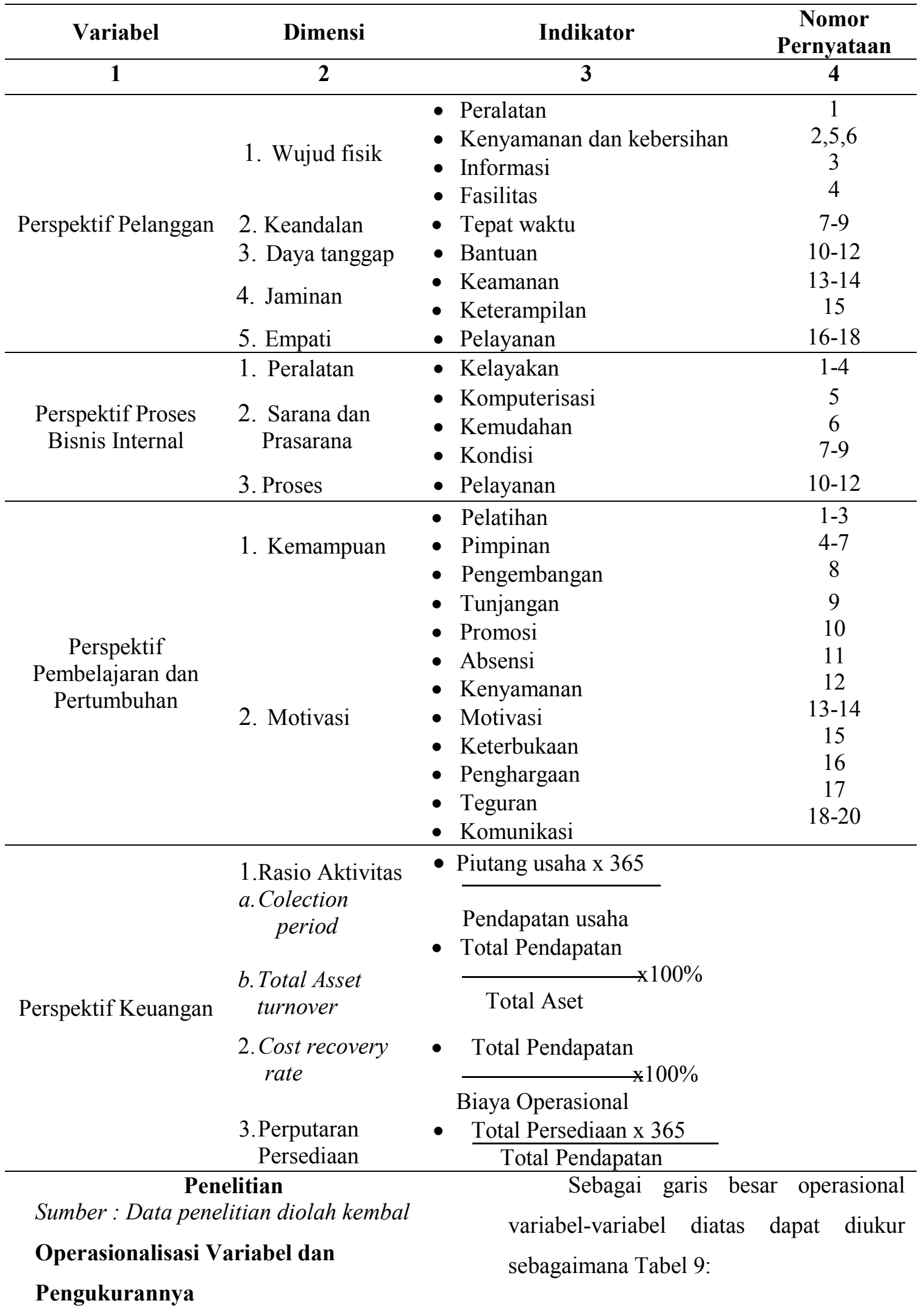


Indikator-indikator diatas baik variabel perspektif pelanggan, perspektif bisnis internal, perspektif pembelajaran dan pertumbuhan maupunperspektif keuangan yaitu menjadi dasar untuk pembuatan kuisioner dan juga sebagai dasar perhitungan, dimana jawaban diberi skor sebagaimana dalam tabel berikut: Skala Likert digunakan mengukur sikap, pendapat, dan persepsi seseorang atau kelompok orang tentang fenomena sosial yang selanjutnya disebut sebagai variabel penelitian. Dengan Skala Likert maka variabel akan diukur dan dijabarkan menjadi indikator variabel kemudian indikator dijadikan titik tolak menyusun item-item pernyataan (Sugiyono, 1999:86).

Penentuan nilai skor dari alternatif pernyataan- pernyataan yang diajukan sebagaimana Tabel 10 berikut:

Tabel 10. Skor atas jawaban pernyataan berdasarkan Skala Likert

\begin{tabular}{cc}
\hline Alternatif Jawaban & $\begin{array}{c}\text { Pemberian } \\
\text { Skala/skor }\end{array}$ \\
\hline Sangat Tidak Setuju/ Sangat Tidak puas & 1 \\
Tidak Setuju/ Tidak puas & 2 \\
Cukup Setuju/ Cukup puas & 3 \\
Setuju/ Puas & 4 \\
Sangat Setuju / Sangat Puas & 5 \\
\hline Sumber : Data penelitian diolah kembali
\end{tabular}

Teknik Pengumpulan Data

Untuk memperoleh data yang dibutuhkan dalam penelitian ini, maka metode pengumpulan data yang dilakukan adalah melalui dokumentasi, wawancara, dan kuesioner.

\section{Teknik Analisis Data}

Adapun metode analisis data yang digunakan sebagai berikut:

1. Analisis Data Distribusi Frekuensi Berdasarkan jawaban kuisioner yang telah terkumpul dan pengolahan data kemudian dilakukan analisis data dengan menghitung distribusi frekuensi dan nilai rata-rata.

a. Distribusi frekuensi yaitu menghitung jumlah responden yang menyatakan sangat puas/sangat setuju,puas/setuju, cukup puas/cukup setuju, tidak puas/tidak setuju, dan sangat tidak puas/ sangat tidak setuju.

b. Nilai rata-rata yaitu menghitung nilai rata-rata masing-masing item maupun variabel. Perhitungan distribusi frekuensi maupun nilai rata-rata dilakukan dengan bantuan software SPSS versi 16.0. 
2. Analisis Perspektif Keuangan

Metode untuk menilai perspektif

keuangan dengan menggunakan

analisis rasio keuangan dan CRR.
Dari metode tersebut diperoleh lima tolak ukur sebagimana disajikan dalam Tabel 11:

Tabel 11. Pengukuran Kinerja Perspektif Keuangan

\begin{tabular}{|c|c|c|c|c|}
\hline No & Tolak Ukur & Cara Pengukuran & Interval Nilai & Hasil \\
\hline \multirow[b]{2}{*}{1} & \multirow[b]{2}{*}{ Collection Period } & Piutang Usaha x 365 & $<36$ hari & Baik \\
\hline & & Pendapatan Usaha & $\begin{array}{c}36-50 \text { hari } \\
>50 \text { hari }\end{array}$ & $\begin{array}{l}\text { Cukup } \\
\text { Kurang }\end{array}$ \\
\hline \multirow{3}{*}{2} & \multirow{3}{*}{$\begin{array}{l}\text { Total Assets } \\
\text { Turnover }\end{array}$} & Total Pendapatan & $90 \%-120 \%$ & Baik \\
\hline & & $-\mathrm{x} 100 \%$ & $40 \%-89 \%$ & Cukup \\
\hline & & Total Aset & $<40 \%$ & Kurang \\
\hline \multirow[b]{2}{*}{3} & \multirow[b]{2}{*}{$\begin{array}{c}\text { Cost Recovery } \\
\text { Rate }\end{array}$} & Total Pendapatan & $>100 \%$ & Baik \\
\hline & & $\frac{}{\text { Biava Operasional }} \times 100 \%$ & $\begin{array}{l}70 \%-99 \% \\
<70 \%\end{array}$ & $\begin{array}{l}\text { Cukup } \\
\text { Kurang }\end{array}$ \\
\hline \multirow[b]{2}{*}{4} & \multirow[b]{2}{*}{$\begin{array}{l}\text { Perputaran } \\
\text { Persediaan }\end{array}$} & Total Persediaan x 365 & $<60$ hari & Baik \\
\hline & & lapatan & $\begin{array}{l}60-150 \text { hari } \\
>150 \text { hari }\end{array}$ & $\begin{array}{l}\text { Cukup } \\
\text { Kurang }\end{array}$ \\
\hline
\end{tabular}

Sumber : Fatmanelly 2010 .

Setelah mendapatkan nilai masing-masing tolak ukur kinerja perspektif keuangan, kemudian hasilnya dibandingkan dengan ukuran atau interval nilai yang ada dan kemudian diberikan skor sesuai dengan kategori hasil yang diperoleh.

3. Dari hasil masing - masing perspektif maka dilakukan penilaian rumahsakit berdasarkan kinerja empat perspektif balanced scorecard.

\section{Karakteristik Responden}

Berdasarkan karakteristik responden terdapat 2 sampel responden yang dilakukan penelitian yaitu pelanggan
Rumah sakit Daerah Madani dan pegawai Rumah Sakit Daerah Madani.

\section{Profil Pelanggan}

Berdasarkan rencana penelitian yang menetapkan 98 responden sebagai sampel pada pelanggan Rumah Sakit Daerah Madani Palu. Karakteristik responden penelitian terdiri dari tiga kategori yaitu :

(1) Jenis kelamin. Karakteristik responden berdasarkan jenis kelamin di dominasi oleh responden dengan jenis kelamin perempuan sejumlah 54 Orang (55\%) sedangkan responden dengan jenis kelamin laki - laki 44 Orang (45\%). Pelanggan yang berjenis kelamin perempuan lebih banyak karena lebih 
banyak pasien ibu - ibu, sehingga dalam pengisian kuesioner didominasi oleh perempuan.

(2) Pendidikan. Karakteristik responden berdasarkan tingkat pendidikan yang terbanyak adalah responden dengan tingkat pendidikan terakhir SMA yaitu sebanyak 47 Orang $(48,0 \%)$, di ikuti oleh SD 26 Orang (26,5\%), SMP 18 Orang (18,4\%), Diploma 5 Orang $(5,1 \%)$ dan S1 2 Orang $(2,0$ \%). Pelanggan pada Rumah Sakit Daerah Madani Palu didominasi dengan tingkat pendidikan SMA, meskipun masih banyak terdapat tingkat pendidikan SD, hal ini dikarenakan banyak pasien yang sudah $>40$ tahun, dan berasal dari desa atau daerah terpencil sehingga tingkat pendidikan mereka hanya sampai SD.

(3) Jenis Fasilitas Kesehatan Pasien. Karakteristik responden berdasarkan jenis fasilitas kesehatan pasien menunjukkan bahwa mayoritas responden menggunakan kartu BPJS sebanyak 80 Orang $(81,6 \%)$, hal ini dikarenakan Pemerintah sudah memberlakukan BPJS kepada setiap masyarakat, sehingga jumlah pengguna BPJS lebih banyak dibandingkan dengan yang umum dengan sebanyak 18 Orang (18, $4 \%$ ).

\section{Profil Pegawai}

Berdasarkan rencana penelitian yang menetapkan 84 responden sebagai sampel pada Pegawai Negeri Sipil pada Rumah Sakit Daerah Madani Palu. Karakteristik responden penelitian terdiri dari tiga kategori yaitu :

(1) Berdasarkan Umur. Pengelompokan responden berdasarkan umur berada pada umur antara 31 s.d 40 tahun sebanyak 46 orang $(54,8 \%)$. Di susul umur 21 s.d 30 tahun sebanyak 22 orang $(26,2 \%)$, dan umur 41 s.d 50 tahun sebanyak 16 orang $(19,0 \%)$. Pada kelompok 31 s.d 40 tahun banyak pegawai yang produktif dan profesional dibidang kerjanya masing - masing serta memiliki jiwa yang semangat untuk bekerja.

(2) Berdasarkan Jenis Kelamin. Profil Respoden berdasarkan jenis kelamin pada Rumah Sakit Daerah Madani Palu, jumlah responden di dominasi oleh responden dengan jenis kelamin perempuan sejumlah 55 Orang $(65,5 \%)$ sedangkan responden dengan jenis kelamin laki-laki sejumlah 29 Orang (34,5\%). Pegawai perempuan lebih banyak dikarenakan perawat atau para medis yang ada lebih didominasi oleh perempuan, hal tersebut menjadi alasan mengapa perempuan lebih banyak daripada laki-laki. 
(3) Berdasarkan masa kerja.

Karakteristik responden berdasarkan masa kerja yang terbanyak adalah responden dengan masa kerja kurang dari 10 tahun yaitu sebanyak 45 orang (54\%), di ikuti 10 s.d 20 tahun sebanyak 28 orang (33\%), dan lebih dari 20 tahun sebanyak 11 orang (13\%). Dari data tersebut menggambarkan bahwa responden pada Rumah Sakit Daerah Madani Palu, memliki masa kerja kurang dari 10 tahun. Karena banyak pegawai yang masa kerjanya diatas 5 tahun hal ini dikarenakan,banyak pegawai yang memiliki umur masih dibawah 40 tahun, dan dengan banyaknya tenaga kerja yang masih produktif sehingga dapat meningkatkan visi misi Rumah Sakit.

(4) Berdasarkan Status Pegawai. Karakteristik responden berdasarkan Status Pegawai seperti pada Gambar 4.8 yang terbanyak yaitu Pegawai dengan status PNS, sebanyak 53 orang $(63 \%)$, di ikuti oleh tenaga kontrak sebanyak 19 orang (23\%), dan tenaga honorer / pegawai tetap non PNS sebanyak 12 orang (14\%). Dari data tersebut menggambarkan bahwa responden pada Rumah Sakit Daerah Madani Palu, rata - rata semua sudah berstatus Pegawai
Negeri Sipil, hal ini juga berperan penting untuk kinerja rumah sakit.

(5) Berdasarkan tingkat pendidikan. Karakteristik responden berdasarkan tingkat pendidikan seperti pada Gambar 4.9 yang terbanyak adalah responden dengan tingkat pendidikan D1 s.d D3 sebanyak 66 orang (70\%), di ikuti oleh Sarajan (S1) sebanyak 19 orang (20\%), Pascasarjana (S2) sebanyak 5 orang $(6 \%)$ dan SMA sebanyak 4 orang (4\%). Dari data tersebut menggambarkan bahwa responden dengan tingkat pendidikan Diploma lebih banyak, hal ini dikarenakan para pegawai didominasi oleh perawat dan kebanyakan dari mereka berpendidikan terakhir Diploma.

\section{HASIL DAN PEMBAHASAN Perspektif Pelanggan}

Dari data di atas, nilai kinerja perspektif pelanggan untuk wujud fisik pasien atau pelanggan merasa puas dengan fasilitas yang ada di rumah sakit dengan nilai rata-rata 3,80. Meskipun terdapat pasien atau pelanggan yang kurang puas karena merasa masih terdapat fasilitas yang belum memadai, misalnya kipas angin di dalam ruangan masih banyak yang tidak berfungsi dengan baik sehingga pasien atau keluarga pasien 
harus menggunakan kipas tangan.

Selain kipas angin contoh lainnya yaitu kurangnya persediaan air dalam toilet, karena daya genset (mesin lampu) yang ada di rumah sakit tidak bisa mencukupi atau memenuhi kebutuhan rumah sakit.

Dari data dibawah, nilai kinerja perspektif pelanggan untuk wujud fisik pasien atau pelanggan merasa puas dengan fasilitas yang ada di rumah sakit dengan nilai rata-rata 3,80. Meskipun terdapat pasien atau pelanggan yang kurang puas karena merasa masih terdapat fasilitas yang belum memadai, misalnya kipas angin di dalam ruangan masih banyak yang tidak berfungsi dengan baik sehingga pasien atau keluarga pasien harus menggunakan kipas tangan. Selain kipas angin contoh lainnya yaitu kurangnya persediaan air dalam toilet, karena daya genset (mesin lampu) yang ada di rumah sakit tidak bisa mencukupi atau memenuhi kebutuhan rumah sakit.

Untuk variabel keandalan mendapat nilai rata-rata 3,78 dengan kategori puas, tetapi masih ada ketidakpuasan dari pasien. Hal ini dikarenakan waktu kunjungan dokter yang tidak menentu sehingga ada keluarga pasien yang merasa menunggu lama. Variabel daya tanggap dengan nilai rata-rata 3,77 dengan kategori puas tetapi nilai ini paling rendah dibandingkan dengan variebel yang lain. Banyak pasien yang mengeluhkan informasi yang diberikan kepada pasien kurang cepat dikarenakan kunjungan dokter yang terlalu lama, meskipun sudah dikunjungi dokter tetapi informasi yang disampaikan kurang akurat sehingga keluarga pasien belum mendapatkan informasi yang kurang jelas dan terkadang dokter terburu-buru dalam melakukan pemeriksaan kepada pasien.

Variabel jaminan memiliki nilai rata-rata 3,84 dengan kategori puas dan nilai tertinggi diantara ke lima variabel yang ada. Hal ini dikarenakan rasa aman, kepercayaan, keramahan, kesopanan, dan keterampilan yang diberikan oleh para petugas medis, suster dan dokter sudah maksimal dalam melayani pasien. Variabel empati memiliki nilai rata-rata 3,79 dengan kategori puas. Namun masih ada pasien yang merasa belum puas dikarenakan masih adanya dokter yang memberikan informasi terburu-buru, sehingga pasien tidak bisa mendapatkan informasi secara detail.

Tabel 12. Nilai Kinerja Perspektif Pelanggan

\begin{tabular}{clcc}
\hline No & \multicolumn{1}{c}{ Variabel } & Nilai Rata - Rata & Kategori \\
\hline 1. & Wujud Fisik (Tangibles) & 3,80 & Puas \\
2. & Keandalan (Reliability) & 3,78 & Puas \\
3. & Daya Tanggap (Responsivennes) & 3,77 & Puas \\
4. & Jaminan (Assurance) & 3,84 & Puas \\
5. & Empati (Emphaty) & 3,79 & Puas \\
\hline \multicolumn{2}{c}{ Nilai rata - rata } & $\mathbf{3 , 7 9}$ & Puas \\
\hline
\end{tabular}


Sumber: Data penelitian telah diolah kembali

\section{Perspektif Proses Bisnis Internal}

Tabel 13. Nilai Kinerja Perspektif Proses Bisnis Internal

\begin{tabular}{clcc}
\hline No & \multicolumn{1}{c}{ Variabel } & Nilai Rata - Rata & Kategori \\
\hline 1. & Peralatan & 3,67 & Setuju \\
2. & Sarana dan Prasarana & 3,61 & Setuju \\
3. & Proses & 3,40 & Setuju \\
\hline \multicolumn{2}{l}{ Nilai Rata - Rata } & $\mathbf{3 , 5 6}$ & Setuju \\
\hline
\end{tabular}

Sumber: data penelitian telah diola kembali

Dari data di atas dapat diketahui nilai kinerja perspektif proses bisnis internal secara keseluruhan memiliki nilai rata-rata 3,56 dengan kategori setuju, tetapi nilai ini sangat rendah dikarenakan variabel peralatan memiliki nilai rata-rata 3,67. Hal ini dikarenakan banyak peralatan masih kurang memadai sehingga menyebabkan para petugas medis dan perawat kesulitan dalam melayani pasien. Variabel sarana dan prasarana memiliki nilai rata-rata 3,61 dengan kategori setuju. Namun, masih banyak pasien yang mengeluhkan minimnya sarana dan prasarana rumah sakit contohnya belum tersedianya komputer di setiap ruangan, seringnya mati lampu dan genset yang ada tidak bisa mememnuhi kebutuhan seluruh ruangan sehingga berakibat minimnya air disetiap toilet. Variabel proses memiliki nilai ratarata 3,40 dengan kategori setuju. Variabel ini memiliki nilai rata-rata paling rendah di antara variabel yang lain, hal ini disebabkan banyaknya pegawai tidak bekerja sesuai bidang ilmunya.

\section{Perspektif Pembelajaran dan Pertumbuhan}

Tabel 14. Nilai Kinerja Perspektif Pembelajaran Dan Pertumbuhan

\begin{tabular}{cccc}
\hline No & \multicolumn{1}{c}{ Variabel } & Nilai Rata - Rata & Kategori \\
\hline 1. & Kemampuan & 3,89 & Setuju \\
2. & Motivasi & 3,73 & Setuju \\
\hline & Nilai Rata - Rata & $\mathbf{3 , 8 1}$ & Setuju \\
\hline
\end{tabular}

Sumber: Data penelitian diolah kembali

Dari data di atas dapat diketahui pelatihan sehingga terampil dalam nilai kinerja perspektif pertumbuhan dan melayani pasien. Variabel motivasi pembelajaran secara keseluruhan memiliki nilai rata-rata 3,73 dengan memiliki nilai rata-rata 3,81 dengan kategori setuju, hal ini disebabkan kategori setuju. Variabel kemampuan tunjangan yang diberikan oleh rumah memiliki nilai rata-rata 3,89 dengan sakit kepada para petugas medis, perawat kategori setuju, hal ini dikarenakan dan dokter sudah memadai. 
Perspektif Keuangan

Tabel 15. Perspektif Keuangan Rumah Sakit Daerah Madani Tahun 2014

\begin{tabular}{|c|c|c|c|c|}
\hline No & Jenis Perhitungan & Rumus & Nilai & Ket \\
\hline \multirow{4}{*}{1.} & $\begin{array}{l}\text { Rasio Aktivitas } \\
\text { a. Collection Period }\end{array}$ & Piutang usaha $\times 365$ & 57 hari & \multirow{2}{*}{$\begin{array}{c}\text { Kurang } \\
\text { baik }\end{array}$} \\
\hline & & Pendapatan Usaha & \multirow{3}{*}{$48 \%$} & \\
\hline & $\begin{array}{l}\text { b. Total Assets } \\
\text { Turnover }\end{array}$ & $\begin{array}{l}\text { Total Pendapatan } \\
\text { x 100\% }\end{array}$ & & \multirow[t]{2}{*}{$\begin{array}{l}\text { Cukup } \\
\text { baik }\end{array}$} \\
\hline & & Total Aset & & \\
\hline 2. & Cost Recovery Rate & $\frac{\text { Total Pendapatan }}{\text { Biaya Operasional }} \times 100 \%$ & $81 \%$ & $\begin{array}{l}\text { Cukup } \\
\text { baik }\end{array}$ \\
\hline \multirow{2}{*}{3} & Perputaran & Total persediaan x 365 & \multirow{2}{*}{32 hari } & \multirow{2}{*}{ Baik } \\
\hline & Persediaan & Total Pendapatan & & \\
\hline
\end{tabular}

Sumber: Data penelitian diolah kembali

Dari data di atas dapat diketahui hasil kinerja perspektif keuangan menunjukkan nilai yang kurang baik. Hal ini disebabkan perputaran piutang rumah sakit kurang baik karena banyaknya pasien khususnya pasien dengan gangguan kejiwaan yang ketika sudah dinyatakan sembuh oleh dokter, keluarga pasien langsung membawa pulang pasien tanpa melunasi administrasi rumah sakit dan ketika pihak rumah sakit mendatangi rumah pasien untuk menagih piutang yang menunggak keluarga pasien tidak bisa melunasi karena keadaan ekonomi yang kurang mampu. Untuk perputaran aktiva mendapatkan nilai $48 \%$ dianggap cukup baik, hal ini disebabkan total pendapatan yang lebih rendah dari pada total aset yang dimiliki. Rendahnya total pendapatan disebabkan banyaknya piutang yang belum tertagih baik dari pasien umum dan pasien yang menggunakan kartu kesehatan.

Selanjutnya dalam hal kemampuan rumah sakit menutup biaya operasionalnya, dianggap cukup baik. Karena banyaknya biaya operasional yang dikeluarkan tidak sebanding dengan total pendapatan yang diperoleh. Perputaran persediaan dianggap baik, dikarenakan banyaknya pasien yang berobat dirumah sakit Madani sehingga penggunaan persediaan rumah sakit seperti obatobatan, infus, dan lain-lain berjalan dengan lancar. 


\section{Pembahasan}

Tabel 16. Kinerja Berdasarkan Balanced Scorecard

\begin{tabular}{|c|c|c|c|c|}
\hline No. & $\begin{array}{l}\text { Perspektif } \\
\text { BSC }\end{array}$ & Variabel & Interpretasi skor & Kategori \\
\hline \multirow{5}{*}{1.} & \multirow{5}{*}{$\begin{array}{l}\text { Perspektif } \\
\text { Pelanggan }\end{array}$} & a. Wujud Fisik & 3,80 & Puas \\
\hline & & b. Keandalan & 3,78 & Puas \\
\hline & & c.Daya tanggap & 3,77 & Puas \\
\hline & & d. Jaminan & 3.84 & Puas \\
\hline & & e.Empati & 3,79 & Puas \\
\hline \multirow{3}{*}{2.} & \multirow{3}{*}{$\begin{array}{l}\text { Perspektif } \\
\text { Proses Bisnis } \\
\text { Internal }\end{array}$} & a. Peralatan & 3,67 & Setuju \\
\hline & & & 3,61 & Setuju \\
\hline & & c.Proses & 3,40 & Setuju \\
\hline \multirow{2}{*}{3.} & $\begin{array}{c}\text { Perspektif } \\
\text { Pembelajaran }\end{array}$ & a. Kemampuan & 3,89 & Setuju \\
\hline & $\begin{array}{c}\text { Dan } \\
\text { Pertumbuhan }\end{array}$ & b. Motivasi & 3,73 & Setuju \\
\hline \multirow{4}{*}{4.} & \multirow{4}{*}{$\begin{array}{l}\text { Perspektif } \\
\text { Keuangan }\end{array}$} & a. Collection Period & 57 hari & Kurang \\
\hline & & b. Total asset turover & $48 \%$ & Cukup \\
\hline & & c. Cost Recovery Rate & $81 \%$ & Cukup \\
\hline & & $\begin{array}{l}\text { Persediaan } \\
\text { Persulan }\end{array}$ & 32 hari & Baik \\
\hline
\end{tabular}

Sumber: Data diolah kembali

Berdasarkan data di atas, dapat diketahui kinerja rumah sakit dengan menggunakan balanced scorecard dapat dilihat bahwa perspektif pelanggan memiliki kategori puas. Hal ini menandakan rumah sakit dalam melayani pasien sangat memperhatikan kebutuhan yang diinginkan pasien atau pelanggan sehingga pasien sebagian besar merasa puas dengan pelayanan yang diberikan oleh rumah sakit, meskipun ada pasien yang merasa kurang puas dengan pelayanan yang diberikan oleh rumah sakit maupun peralatan yang kurang memadai namun hal ini tidak mengurangi kepuasan sebagian besar pasien.
Perspektif proses bisnis internal memiliki nilai yang tidak terlalu tinggi, tetapi dalam kategori setuju. Ini dikarenakan perlatan rumah sakit yang masih kurang atau minim dalam melayani pasien sehingga nilai dari proses bisnis internal sangat rendah. Perspektif pembelajaran dan pertumbuhan memiliki nilai yang sangat bagus hal ini dikarenakan pelatihan dan pengembangan karyawan yang dilaksanakan oleh rumah sakit Madani sangat rutin dilakukan setiap tahun. Sehingga membuat karyawan terampil dalam melayani pasien. Perspektif keuangan memiliki nilai yang kurang baik, dari segi perputaran piutang, perputaran aktiva dan juga kemampuan 
rumah sakit menutupi biaya operasional.

Sementara dari segi perputaran persediaan memiliki nilai yang baik.

Dari keempat perspektif, nilai yang baik adalah perspektif pelanggan dan perspektif pembelajaran dan pertumbuhan. Dari sisi perspektif pelanggan menunjukkan bahwa sebagian besar pasien merasa puas dengan pelayanan yang diberikan oleh pihak rumah sakit. Begitu pula dengan perspektif pembelajaran dan pertumbuhan menunjukkan bahwa pihak rumah sakit rutin melakukan pelatihan terhadap para pegawai rumah sakit sehingga para pegawai terampil dalam melayani pasien. Sedangkan nilai yang paling rendah adalah perspektif keuangan. Hal ini menunjukkan bahwa masih banyaknya piutang rumah sakit yang menunggak sehingga menyebabkan pendapatan rumah sakit rendah.

Tabel 17. Hasil Penilaian Kinerja Rumah Sakit Daerah Madani Dengan Menggunakan Balanced Scorecard

\begin{tabular}{lll}
\hline \multicolumn{1}{c}{ Perspektif } & Kategori & Skor \\
\hline Pelanggan & & \\
1. Wujud Fisik (Tangibles) & Puas & 1 \\
2. Keandalan (Reliability) & Puas & 1 \\
3. Daya Tanggap (Responsivennes) & Puas & 1 \\
4. Jaminan (Assurance) & Puas & 1 \\
5. Empati (Emphaty) & Puas & 1 \\
Rata - rata & Puas & 1 \\
\hline Proses Bisnis Internal & & \\
1. Peralatan & Setuju & 1 \\
2. Sarana dan Prasarana & Setuju & 1 \\
3. Proses & Setuju & 1 \\
$\quad$ Rata - rata & Setuju & 1 \\
\hline Pembelajaran dan Pertumbuhan & & \\
1. Kemampuan & Setuju & 1 \\
2. Motivasi & Setuju & 1 \\
Rata - rata & Setuju & 1 \\
\hline
\end{tabular}

Keuangan Rasio Aktivitas

1. Collection Period

2. Total Assets Turnover

Kurang $\quad-1$

3. Cost Recovery Rate

Cukup

0

4. Perputaran Persediaan

Cukup

Rata - Rata

Baik

Cukup

0

Sumber: Data Sekunder Diolah

1

Langkah selanjutnya adalah

pembuatan skala untuk menilai total skor tersebut agar mempermudah dalam penilaian, sehingga kinerja perusahaan dapat dikatakan "kurang", "cukup", dan "baik". Sehingga rata-rata skor adalah $10 / 14=0,7$ Dengan menggunakan skala (Mulyadi, 2001), maka dapat diketahui 
kinerja rumah sakit. Berikut ini adalah

gambar skala kinerja rumah sakit:

\section{Skala Kinerja}

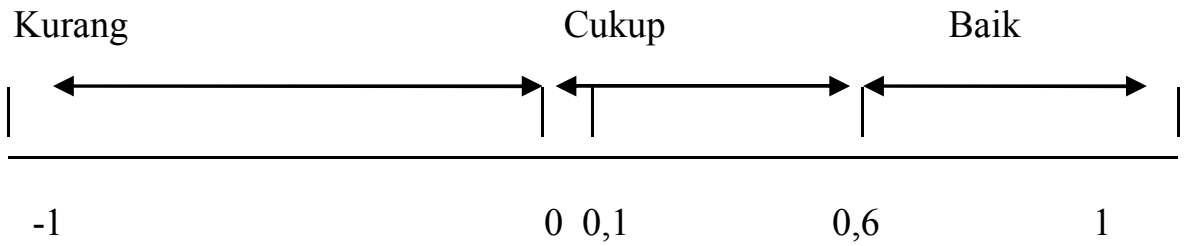

Dengan demikian dapat diartikan

bahwa dengan menggunakan balanced scorecard Rumah Sakit Daerah Madani akan terletak didaerah "Baik" karena 0,7 terletak diantara $0,6-1$.

Empat perspektif Balanced Scorecard merupakan suatu kesatuan yang memiliki hubungan sebab akibat. Jika Rumah Sakit Daerah Madani menginginkan dimensi keuangan yang dapat diperoleh naik secara terus menerus dan berlipat ganda, maka Rumah Sakit Daerah Madaniharus dapat memberikan kepuasan kepada pelanggannya. Pelanggan yang puas akan datang apabila ditunjang oleh kinerja karyawan rumah sakit yang baik, sehingga akan meningkatkan nilai proses pelayanan. Kinerja yang baik ditunjang dengan kepuasan kerja karyawan terhadap pekerjaannya. Dengan kepuasan yang baik maka karyawan akan bekerja dengan maksimal, sehingga akan mempengaruhi keuangan rumah sakit nantinya. Setelah dilakukan analisis terhadap keempat perspektif dalam Balanced Scorecard, selajutnya adalah memberikan skor pada masing-masing perspektif. Dari hasil skoring diperoleh total skor sebesar 0,7 yang artinya kinerja Rumah Sakit Daerah Madani dalam kategori baik.

Namun, jika dilakukan perbandingan antara aspek internal dan eksternal unit, perbandingan antara aspek pelanggan dan aspek karyawan, serta perbandingan aspek keuangan dan non keuangan ditemui adanya ketidakseimbangan dimana unit lebih cenderung fokus pada aspek internal, aspek orang, dan aspek non keuangan. Seperti disebutkan oleh Mulyadi (2007), kecenderungan pada aspek internal dapat mempengaruhi kepuasan pelanggan dan pemegang saham sehingga dapat mempengaruhi kemampuan rumah sakit dalam menghasilkan kinerja keuangan dalam jangka panjang. Selain itu, cenderung kepada aspek pelanggan juga akan mengakibatkan proses bisnis internal dan keuangan terabaikan, dan nantinya akan mempengaruhi kemampuan rumah sakit dalam menghasilkan kinerja keuangan jangka panjang. Untuk itu, hendakanya Rumah Sakit memperbaiki 
fokusnya sehingga dapat terjadi keseimbangan antara aspek internal dan eksternal, serta aspek keuangan dan non keuangan dengan cara mengoptimalkan hasil dari empat perspektif balanced scorecard.

\section{KESIMPULAN}

Berdasarkan hasil penelitian dan pembahasan dengan menggunakan Balanced Scorecard, dapat disimpulkan sebagai berikut:

1. Perspektif Pelanggan memperoleh nilai rata - rata 3,79 dalam kategori puas, hal ini berarti pelanggan merasa puas dengan semua pelayanan yang diberikan oleh Rumah Sakit Daerah Madani.

2. Perspektif proses bisnis internal memperoleh nilai rata - rata 3,56 yang dikategorikan setuju, oleh karena itu dapat diartikan bahwa untuk melakukan pelayanan ditunjang dengan peralatan, sarana dan prasarana serta proses pelayanan pada Rumah Sakit Daerah Madani, mayoritas menyatakan setuju dengan fasilitas yang ada.

3. Perspektif pembelajaran dan pertumbuhan memperoleh nilai rata rata 3,81 yang dikategorikan setuju, sehingga dapat dikatakan bahwa kemampuan dan motivasi yang diberikan oleh Rumah Sakit Daerah
Madani dalam menunjang pekerjaan, mayoritas pegawai mengatakan setuju dengan motivasi yang diberikan kepada karyawan.

4. Perspektif keuangan dalam hal ini memperoleh kategori cukup dari masing - masing rasio yang ada, dimana rasio ini yang memiliki nilai kurang baik yaitu collection perioed yang memperoleh nilai 57 hari sehingga Rumah Sakit Daerah Madani lama dalam penagihan piutangnya.

Hasil kinerja Rumah Sakit Daerah Madani melalui empat perspektif yaitu perspektif pelanggan, perspektif proses bisnis internal, perspektif pembelajaran dan pertumbuhan dan perspektif keuangan dilihat dari skala kinerja rumah sakit, rumah sakit mendapatkan nilai 0,7 maka kinerja Rumah Sakit Daerah Madani berdasarkan Balanced Scorecard dikategorikan baik.

\section{KETERBATASAN}

Dalam penelitian ini peneliti mempunyai beberapa keterbatasan, antara lain :

1. Keterbatasan waktu dari pasien dan pegawai Rumah Sakit Daerah Madani Palu untuk mengeksplor keteranganketerangan yang dibutuhkan oleh peneliti terbatas.

2. Pasien atau keluarga pasien tidak terlalu memahami dengan kuesioner 
yang dibagikan. Sehingga peneliti harus membacakan atau memberikan arahan yang jelas, agar pasien atau keluarga pasien dapat mengerti dengan pernyataan yang dibuat oleh peneliti.

3. Pegawai yang sibuk dengan pelayanannya kepada pasien dan terkadang sulit untuk dimintai keterangan, tetapi peneliti menunggu sampai responden yang diinginkan mau untuk mengisi kuesioner demi untuk keakuratan data yang peneliti inginkan.

\section{SARAN}

Dari beberapa permasalahan yang ada maka dapat diberikan saran bahwa:

1. Untuk perspektif pelanggan dalam hal wujud fisik perlu meningkatkan fasilitas yang ada. Untuk keandalan, setiap dokter yang melakukan pemeriksaan kepada pasien diharapkan untuk memberikan peluang atau waktu kepada pasien sehingga pasien dapat bertanya sesuai dengan keluhannya. Untuk jaminan, diharapkan dokter maupun perawat melakukan pelatihan yang rutin setiap tahun agar lebih meningkatkan keterampilannya dan pengetahuan sehingga apa yang menjadi keluhan pasien dapat segera tertangani oleh dokter dan perawat.

2. Untuk perspektif proses bisnis internal dalam hal peralatan, Rumah Sakit
Daerah Madani perlu menambah peralatan medis. Hal ini dikarenakan banyaknya peralatan yang masih belum lengkap sehingga membuat penanganan terhadap pasien sering mengalami keterlambatan. Dalam hal sarana dan prasarana, perlu memperhatikan kekurangan yang ada di rumah sakit misalnya WC, air, genset dan lain sebagainya. Ini dapat membuat pasien tidak nyaman karena seringnya sarana yang ada tidak sesuai dengan kebutuhan pasien.

3. Untuk perspektif pembelajaran dan pertumbuhan dalam hal kemampuan, pimpinan rumah sakit harus sering melakukan evaluasi terhadap kinerja para bawahannya agar pegawai yang ada dapat dilihat kekurangannya dan juga dapat ditingkatkan kemampuannya melalui pelatihan. Apabila terdapat pegawai yang tidak bekerja sesuai dengan bidang ilmunya. Dalam hal motivasi, pemberian tunjangan dan insentif harus diperhatikan agar dapat meningkatkan gairah para pegawai dalam bekerja karena hal ini sangat penting untuk meningkatkan kinerjanya.

4. Untuk perspektif keuangan, Rumah Sakit Daerah Madani dalam hal ini harus lebih memperhatikan pasien yang masuk dengan melihat kartu yang digunakan sehingga ketika pasien 
keluar dari rumah sakit ada pertanggung jawaban pasien kepada Rumah Sakit dan untuk pasien umum harus ada surat keterangan dari kepala desa yang memberikan keterangan bahwa pasien yang bersangkutan memiliki kategori kurang mampu sehingga Rumah Sakit sudah memiliki informasi terlebih dahulu.

\section{DAFTAR PUSTAKA}

BPKP. 2004. Pengukuran dan Evaluasi Kinerja Instansi Pemerintah. Jakarta BPKP

Gaspersz, Vincent. 2006. sistem Terintgrasi : balanced Scorecard dengan Six Sigma untuk Organisasi Bisnis dan Pemerintah, Gramedia, Cetakan Kedua Jakarta.

Kaplan, Robert S dan Norton, David P. 1996. Balanced Scorecard, Penerbit Erlangga, Jakarta.

Kaplan, Robert S dan Norton, David P. 2001. Balanced Scorecard: Menerapkan Strategi menjadi Aksi, Penerbit Erlangga, Jakarta.

Kuncoro, Mudrajat. 2007. Metode Kuantitatif, Teori dan Aplikasi untuk Bisnis dan Ekonomi, UPP STIM YKPN, Yogyakarta.

Mardiasmo. (2002). Akuntansi Sektor Publik. Penerbit Andi. Yogyakarta.

(2004). Otonomi dan Manajemen Keuangan daerah. Penerbit Andi. Yogyakarta

Mulyadi. 2001. Balanced Scorecard Alat Manajemen Kontemporer untuk
Pelipatganda Kinerja Keuangan Perusahaan, Salemba Empat, Jakarta.

2003. Ekonomi Sumber Daya Manusia - Dalam Perspektif Pembangunan, Penerbit PT. Rajagrafindo Persada, Jakarta.

$\begin{array}{lrr}\text { Kinerja } & \text { Alternatif } & \text { Pemacuan } \\ \text { Balanced } & \text { Scorecard } & \text { Berbasis } \\ \text { Ekonomi Dan Bisnis } & \text { Indonesia } \\ \text { Vol. 20, No.3. } & \end{array}$

Mulyadi dan Jony Setiawan. 2000. Sistem Perencanaan dan Pengendalian Manajemen Edisi ke-2 Jakarta PT. Salemba 4.

Mulyadi dan Jony Setiawan. 2001. Sistem Perencanaan dan Pengendalian manajemen: Sistem Pelipatgandaan Kinerja Keuangan Perusahaan, Salemba Empat: Jakarta

Republik Indonesia. Undang - Undang Nomor 1 Tahun 2004 tentang Perbendaharaan Negara

$\begin{array}{lr}\text { Peraturan } & \text { Menteri } \\ \text { Dalam Negeri } & \text { Nomor 61 } \\ \text { Tahun 2007 } & \text { tentang } \\ \text { Pedoman } & \text { Teknis } \\ \text { pengelolaan } & \text { Keuangan } \\ \text { Badan Layanan } & \text { Umum } \\ \text { Daerah } & \end{array}$

Siagian, Sondang. 1995. Teori Motivasi dan Aplikasinya. PT Rineka Cipta, Jakarta Slamet, Achmad. 2007. Manajemen Sumber Daya manusia Semarang UNNES Press.

Sugiyono.2006. Metode Penelitian Administrasi Dilengkapi Dengan Metode R\&D. Alifa Beta Bandung. 
JRAMB, Prodi Akuntansi, Fakultas Ekonomi, UMB Yogyakarta

Volume 3 No. 1., Mei 2017

ISSN : 2460-1233

2009. Metode Penelitian Kuantitatif dan Kualitatif. CV. Alfabets. Bandung.
Sugiyono. 2012. Metode Penelitian Kombinasi. Alfabeta. Bandung. 